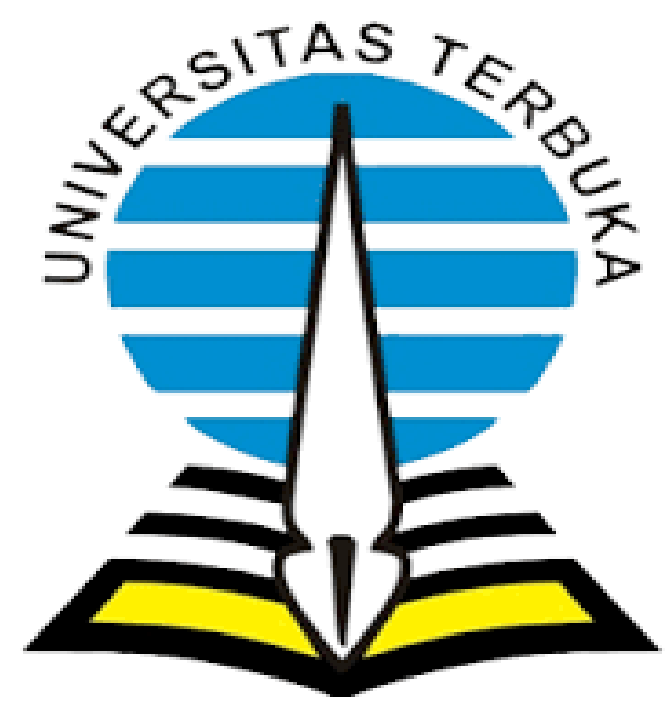

Disusun oleh :

Suhaemi

PROGRAM STUDI S.1 PGSD

POKJAR DEPOK

UNIVERSITAS TERBUKA

POKJAR DEPOK

TAHUN AJARAN 2019-2020 


\section{HAKIKAT, LANDASAN, DAN KURIKULUM PENDIDIKAN IPS DI SD}

\section{Pendahuluan}

Hakikat dan Tujuan, Landasan, dan Perkembangan Kurikulu IPS bukanlah hal yang benarbenar baru. Namun, sebagai guru professional hakikatnya adalah menjadi agen pembaharuan yang berperan sebagai pemimpin dan pendukung nilai-nilai dalam masyarakat dan sebagai fasilitator dalam pembelajaran. Menjadi guru IPS yang baik seorang guru diharapkan memiliki dasar-dasar pembelajaran IPS karena membelajarkan IPS di SD bukan berarti mengajarkan ilmu-ilmu sosial, melainkan membelajarkan konsep-konsep esensi ilmu sosial untuk membentuk peserta didik menjadi warga Negara yang baik.

Tujuan Pembelajaran Umum setelah mempelajari bahasan ini adalah kita diharapkan dapat menganalisis Hakikat Pendidikan IPS SD. Secara khusus dapat diperinci dalam bentuk perilaku sebagai berikut.

1. Menjelaskan Hakikat dan Tujuan pendidikan IPS di SD.

2. Menjelaskan Landasan Pendidikan IPS di SD

3. Menjelaskan perkembangan Kurikulum Pendidikan IPS di SD

\section{KEGIATAN BELAJAR 1}

\section{Hakikat dan Tujuan Pendidikan IPS}

Setiap orang sejak lahir, tidak terpisahkan dari manusia lain, khususnya dari kedua orang tuanya. Sejak itu si bayi telah melakukan hubungan dengan orang lain. Hubungan sosial telah terjadi. Sesuai dengan penambahan umur dan pengalaman maka hubungan sosial itu semakin meluas. Pengetahuan yang melekat pada diri seseorang itu dapat dirangkum sebagai "Pengetahuan Sosial". Pengalamannya di masyarakat dan bermasyarakat telah membentuk pengetahuan sosial dalam dirinya masing-masing. Sedangkan "Pengetahuan Sosial" secara resmi baru diketahui setelah kita secara formal bersekolah. 


\section{A. HAKIKAT PENDIDIKAN IPS DI SD}

Ilmu Pengetahuan Sosial (IPS) bukanlah disiplin ilmu melainkan suatu program pengajaran atau mata pelajaran yang mempelajari kehidupan sosial yang kajiannya mengintegrasikan bidang ilmu-ilmu sosial (ilmu sejarah, ilmu geografi, ilmu ekonomi, dan ilmu sosiologi) dan humaniora (aspek norma, nilai, bahasa, seni, dan budaya)

Meskipun pengetahuan sosial sesungguhnya sudah melekat pada diri seseorang namun IPS perlu dipelajari dan diajarkan kepada peserta didik. Hal ini dikarenakan pengetahuan sosial alamiah itu belum cukup mengingat kehidupan masyarakat dengan segala persoalannya itu makin berkembang. Untuk menghadapi perkembangan yang terus menerus tersebut diperlukan pendidikan formal, khususnya pendidikan IPS di sekolah.

\section{B. TUJUAN PENDIDIKAN IPS DI SD}

Pendidikan IPS bertujuan "membina peserta didik menjadi warga negara yang baik, yang memiliki pengetahuan, keterampilan dan kepedulian sosial, yang berguna bagi dirinya sendiri serta bagi masyarakat dan negara". Untuk merealisasikan tujuan ini maka proses pembelajaran IPS tidak hanya menekankan pada aspek pengetahuan (kognitif), dan keterampilan (psikomotor) saja, melainkan meliputi juga aspek akhlak (afektif) dalam menghayati serta menyadari kehidupan yang penuh dengan masalah, tantangan, hambatan, dan persaingan.

Melalui pendidikan IPS peserta didik dibina dan dikembangkan kemampuan mental intelektualnya menjadi warga negara yang berketerampilan dan berkepedulian social serta bertanggung jawab sesuai dengan nilai-nilai yang terkandung dalam Pancasila. Guru IPS di SD perlu memiliki wawasan tujuan dan arah yang hendaknya dipertimbangkan ketika mengembangkan materi pembelajaran. Lima kriteria dalam mengembangkan materi pembelajaran yaitu Pembelajaran IPS di SD hendaknya:

- Mengembangkan kemampuan memahami berbagai fenomena sosial yang akanberguna dalam proses pengambilan keputusan.

- Mengembangkan kemampuan komunikasi social yakni keterampilan menangkap berbagai fenomena social.

- Mengembangkan kemampuan dasar dalam memecahkan masalah social 
- Mengembangkan kemampuan sikap peka, tanggap, dan adaftif tetapi tetap kritis yaitu mampu menggunakan logika dan fakta dalam mengambil kesimpulan/keputusan. (mencari sebab, memprediksi, menganalisis, melihat keterpaduan berbagai fenomena serta menganalisis secara logis dan sistematis)

- Mengembangkan kemampuan menganalisis masalah social secara terpadu.Adapun fungsi IPS sebagai pendidikan yaitu:

- Membekali peserta didik dengan pengetahuan social yang berguna yang dapat diterapkan sehari-hari,

- Mengembankan keterampilan terutama keterampilan social, keterampilan intelektual,

- Mengembangkan kepedulian social

\section{KEGIATAN BELAJAR 2}

\section{Landasan Pendidikan IPS SD}

\section{A. LANDASAN PENDIDIKAN IPS SEBAGAI PENDIDIKAN DISIPLIN ILMU}

1. Landasan Filosofis: Memberikan gagasan pemikiran mendasar yang digunakan untuk menentukan objek kajian (domain) yang menjadi kajian pokok dan dimensi pengembangan Pendidikan IPS sebagai disiplin ilmu (aspek ontologis/bersifat kongkret), bagaimana cara, proses, atau metode membangun Pendidikan IPS hingga dapat menentukan pengetahuan mana yang dianggap benar, sah, valid, atau terpercaya (aspek epistemologis/hakikat rasional), tujuan dan manfaat dari pendidikan IPS ini (aspek aksilogis/nilai/bagaimana manusia menggunakan ilmunya).

2. Landasan Ideologis: Sistem gagasan untuk memberi pertimbangan dan menjawab pertanyaan; (1) Keterkaitan antara das sein/fakta pendidikan IPS sebagai disiplin ilmu dengan das sollen/teori pendidikan IPS, (2) Keterkaitan antara teori-teori pendidikan dengan hakikat dan praksis etika, moral, politik, dan norma-norma perilaku dalam membangun dan mengembangkan pendidikan IPS.

3. Landasan Sosiologis: Sistem gagasan mendasar untuk menentukan cita-cita, kebutuhan, kepentingan, kekuatan, aspirasi, serta pola kehidupan masa depan melalui interaksi social yang akan membangun teori/prinsip pendidikan IPS sebagai pendidikan disiplin ilmu.

4. Landasan Antropologis: Sistem gagasan mendasar dalam menentukan pola, system, dan struktur pendidikan disiplin ilmu sehingga relevan dengan pola, system, dan struktur 
kebudayaan. Landasan ini memberikan dasar sosio-kultur masyarakat terhadap IPS sebagai pendidikan disiplin ilmu.

5. Landasan Kemanusiaan: Sistem gagasan mendasar untuk menentukan karakter ideal manusia. Landasan ini penting karena pada dasarnya proses pendidikan adalah proses memanusiakan manusia.

6. Landasan Politis: menentukan arah dan garis kebijakan dalam politik pendidikan dari pendidikan IPS. Peran dan keterlibatan pihak pemerintah dalam landasan ini sangat besar sehingga tidak mungkin steril dari campur tangan birokrasi.

7. Landasan Psikologis: menentukan cara-cara Pendidikan IPS membangun struktur tubuh disiplin pengetahuannya, baik dalam tataran personal maupun komunal berdasar entitas psikologisnya.

8. Landasan Religius: tentang nilai-nilai, norma, etika, dan moral yang menjadi jiwa (ruh) yang melandasi Pendidikan IPS, khususnya di Indonesia. Landasan religious diterapkan di Indonesia menghendaki adanya keseimbangan antara pengembangan materi yang bersumber dari intraceptive knowledge dengan extraceptive knowledge

\section{B. LANDASAN FILOSOFIS PENDIDIKAN IPS SD}

\section{Landasan Filosofis Guru IPS dalam Perubahan Zaman}

Untuk mengimbangi perkembangan dan kemajuan zaman, guru harus mampu melakukan seleksi aneka kecenderungan peserta didik dalam mengarahkan proses pembelajaran pendidikan IPS. Guru harus pandai memanfaatkan kemajuan ini tetapi tetap dalam koridor kurikulum yang dipakai.

Ada dua aliran filsafat ekstremitas yakni sikap reaksioner (hati-hati dan takut pembaharuan) dan sikap radikal (sangat mendukung pembaharuan). Menyikapi hal itu, guru IPS dapat menempati salah satu dari empat titik utama yang terletak diantara dua ekstremitas tersebut, yaitu:

a. Perenialisme: keyakinan adanya kebenaran yang sifatnya abdi dan mutlak. (faham ini berakar pada filsafat Thomas Aquino)

b. Esensialisme: faham bahwa ada hakikat minimum tertentu yang harus dipertahankan sekolah (hasil endapan pengetahuan dan kebijaksanaan masa lampau) yang perlu diestafetkan. 
c. Progresivisme: faham bahwa sesuatu harus dilakukan secara ilmiah, dan sekolah sebagai pendahulunya. (faham John Dewey terhadap pragmatism)

d. Rekonstruksionisme: mirip progresivisme tetapi lebih maju, secara kongkrit lebih mendekati tujuan ideal yaitu sekolah menjadi pelopor usaha pembaharuan masyarakat.

\section{Landasan Filosofis Pengembangan Kurikulum Pendidikan IPS SD}

Penyusunan kurikulum pendidikan IPS di SD, langkah awalnya didasarkan pada penetapan landasan filsafat apa yang akan digunakan. Perlu ditekankan bahwa landasan filosofis yan akan digunakan harus sesuai dengan corak budaya masyarakat.

Pendidikan IPS di SD merupakan suatu synthetic antara disiplin ilmu pendidikan dan disiplin ilmu social maka pengembangannya diarahkan untuk tujuan pendidikan khususnya pendidikan dasar. Pada tahap penyajiannya harus disesuaikan dengan landasan edukatif pendidikan IPS di SD. Artinya materi yang diberikan harus dilakukan proses penyederhanaan dengan mempertimbangkan psikologis atau tingkat kematangan peserta didik.

Berdasarkan uraian tersebut, factor dan unsur-unsur yang terkandung dalam pendidikan IPS bermuara pada tujuan. Dimana tujuan itu meliputi pengembangan intelektual, kemampuan individual serta peranannya dalam masyarakat. Dalam tradisi pengembangan kurikulum pendidikan IPS SD di Indonesia dipengaruhi berbagai aliran filsafat, diantaranya:

a. Aliran filsafat esensialisme. Kecemerlangan ilmu harus menjadi kepedulian setiap generasi sebab hanya melalui penguasaan ilmu, masyarakat akan berkembang. Pengaruh pemikiran filsafat ini adalah:

- Pendidikan IPS disajikan secara terpisah dengan keilmuannya itu sendiri

- Memandang bahwa sasaran utama sekolah adalah memperkenalkan peserta didik pada karakteristik dasar alam semesta yang sudah mapan dengan cara mewariskan budaya yang sudah berkembang sepanjang zaman.

- Menempatkan peserta didik sebagai peserta yang menerima warisan nilai yang ditransmisikan guru.

b. Aliran filsafat eklekitikisme. Merupakan perpaduan antara esensialis dengan campur tangan kepentingan pendidikan. Pendidikan IPS dikembangkan dalam bentuk pendekatan korelasi dan terpadu. 
c. Aliran filsafat perenialisme. Liberal arts artinya pengembangan intelektualisme didasarkan dan ditujukan untuk mengembangkan dan melestarikan nilai-nilai luhur bangsa, berbicara tentang keagungan dan kejayaan bangsa. Menghendaki adanya pewarisan nilai dari generasi ke generasi. Menekankan pada transfer of culture.

d. Aliran filsafat progressivisme. Tujuan utama sekolah adalah untuk meningkatkan kecerdasan praktis yang membuat siswa lebih efektif dalam memecahkan berbagai masalah yang disajikan dalam konteks pengalaman siswa pada umumnya.

e. Aliran filsafat rekonstruksi social. Aliran ini memandang pendidikan sebagai wahana untuk mengembangkan kesejahteraan social. Sekolah harus diarahkan pada kepada pencapaian tatanan demokratis yang mendunia.

\section{LANDASAN OPERASIONAL PENDIDIKAN IPS SD}

- Bab III Pasal 2 UU No. 20/2003 tentang Sistem Pendidikan Nasional Repulik Indonesia.

- Permendiknas No. 22/2006 tentang standar isi

- PP No. 19/2005 tentang Kelompok mata pelajaran

- Kepmendiknas No. 22/2006 tentang KTSP

\section{KEGIATAN BELAJAR 3}

\section{Perkembangan Kurikulum Pendidikan IPS SD}

Kurikulum IPS SD Tahun 2006 dalam KTSP yang ditetapkan berdasarkan Kepmendiknas RI 22/2006 mempunyai karakteristik tersendiri karena tidak menganut istilah Pokok Bahasan (PB), Namun Standar Kompetensi (SK) dan Kompetensi Dasar (KD). Hal ini jauh lebih sederhana dengan jam pelajaran yang relative lebih sedikit.

Memberikan peluang yang luas bagi guru untuk berkreasi dalam pengembangan kurikulum yang mengacu pada pembelajaran IPS yang PAKEM. Kurikulum 2006 lebih simple dan efektif, namun memiliki nuansa yang padat. Kurikulum Pendidikan IPS SD Tahun 2006 bersifat hanya memberi rambu-rambu untuk kedalaman dan keluasan materi dalam mencapai KD yang diharapkan. Di dalam KD terdapat kata kerja operasional yang disarankan dan mengacu pada pembelajaran yang kreatif. Kelas 1, 2, dan 3 dilaksanakan menggunakan pendekatan tematik sedangkan kelas 4 sampai 6 melalui pendekatan mata pelajaran. 
Berbeda halnya dengan Kurikulum IPS tahun 1994 materi pelajaran ditata secara lebih terpadu dan lebih sederhana daripada materi Kurikulum IPS 1986 dan 1975 yang masih tampak berdiri sendiri-sendiri. Materi Kurikulum 1994 merupakn korelasi antara berbagai disiplin ilmu penunjangnya. Berbeda dengan kurikulum sebelumnya (1986, 1975, dan 1968). Materi Kurikulum 1968 masih berdiri sendiri dan merupakan broad-field antara Ilmu Bumi, Sejarah, dan Pengetahuan Kewarganegaraan. Pada Kurikulum 1975 Pendidikan Kewarganegaraan dipisah menjadi PMP. Pada Kurikulum 1994 PMP berganti nama menjadi PPKN.

Dari segi tujuan kurikuler, Kurikulum 1964/1968 menekankan pada moral. Unsur moral tersebut terwadahi dalam bidang studi PMP/PPKN pada Kurikulum 1975, 1986, dan 1994. Kurikulum 1986 dan 1994 sama-sama mempunyai 4 tujuan kurikuler. Dari segi bahan ajar, Kurikulum 1994 tetap menggunakan Pendekatan Spiral. Khusus untuk sejarah mengunakan pendekatan periodisasi. Sejarah di Kurikulum 1986 tidak seluas kurikulum 1975 karena ada mata pelajaran PSPB.

Dari segi alokasi waktu pada dasarnya tidak berbeda antara kurikulum 1986 dengan 1994, namun pada kurikulum 2006 relatif lebih sedikit yakni 3x35 menit. Perbedaan yang lebih esensi ada pada jumlah PB. Kurikulum 1986 padat dan sarat materi sehingga keluasan materi terbatasi, sedangkan Kurikulum 1994 keluasan materi diserahkan kepada guru dan di Kurikulum 2006 lebih simple lagi.

\section{Perbedaan Kurikulum IPS SD Tahun 1994 dan Kurikulum Tahun 2006 :}

\section{A. Kurikulum tahun 1994}

Dalam Kurikulum SD tahun 1994 lebih menekankan hal-hal berikut.

1. Membaca, menulis dan berhitung

2. Muatan lokal

3. Ilmu Pengetahuan dan Teknologi (IPTEK)

4. Wawasan lingkungan

5. Pengembangan nilai

6. Pengembangan keterampilan 


\section{B. Kurikulum tahun 2006}

Pada Kurikulum SD Tahun 2006 lebih menekankan hal-hal berikut.

1. Kerangka Dasar

Kelompok Mata Pelajaran dibuat berdasarkan PP 19/2005 tentang SNP yang menyatakan bahwa kurikulum untuk jenis pendidikan umum, kejuruan, dan khusus pada jenjang pendidikan dasar dan menengah terdiri atas:

a. Kelompok mata pelajaran agama dan akhlak mulia;

b. Kelompok mata pelajaran kewarganegaraan dan kepribadian;

c. Kelompok mata pelajaran ilmu pengetahuan dan teknologi;

d. Kelompok mata pelajaran estetika;

e. Kelompok mata pelajaran jasmani, olahraga, dan kesehatan.

2. Prinsip Pengembangan Kurikulum

KTSP dikembangkan oleh sekolah dan komite sekolah berpedoman pada Standar Kompetensi Lulusan dan Standar Isi serta panduan dari BSNP. Kurikulum dikembangkan berdasarkan prinsip:

a. Berpusat pada potensi, perkembangan, kebutuhan, dan kepentingan peserta didik serta lingkungannya.

b. Beragam dan terpadu

c. Tanggap terhadap perkembangan ilmu pengetahuan, teknologi, dan seni

d. Relevan dengan kebutuhan kehidupan

e. Menyeluruh dan berkesinambungan

f. Belajar sepanjang hayat

g. Seimbang antara kepentingan nasional dan kepentingan daerah.

3. Prinsip Pelaksanaan Kurikulum

Dalam pelaksanannya digunakan prinsip-prinsip, yaitu:

a. Didasarkan pada potensi, perkembangan dan kondisi peserta didik

b. Dilaksanakan dengan menegakan lima pilar belajar

c. Memungkinkan peserta didik mendapatkan pelayanan belajar yang optimal 
d. Dilaksanakan dalam suasana hubungan peserta didik dan pendidik yang saling menerima dan menghargai.

e. Dilaksanaan dengan menggunakan pendekatan multistrategi dan multimedia, sumber belajar dan teknologi yang memadai dan memanfaatkan lingkungan sekitar.

f. Dilaksanakan dengan mendayagunakan kondisi alam, social dan budayanya

g. Mencakup seluruh komponen kempetensi mata pelajaran, mulok, dan pengembangan diri.

\section{Struktur Kurikulum SD}

Struktur kurikulum SD meliputi substansi pembelajaran yang ditempuh dalam satu jenjang pendidikan selama enam tahun mulai kelas I s.d. kelas VI. Struktur kurikulum disusun berdasarkan standar kompetensi lulusan dan standar kompetensi. Kurikulum SD memuat 8 mata pelajaran, muatan lokal, dan pengembangan diri.

\section{Referensi}

Sulfemi, Wahyu Bagja. (2009). Modul Pembelajaran Pendidikan Pancasila dan Kewarganegaraan. Bogor: STKIP Muhammadiyah Bogor, 1, 1-49.

Sulfemi, Wahyu Bagja. (2016). Modul Pembelajaran Ilmu Sosial dan Budaya Dasar. Bogor : STKIP Muhammadiyah Bogor.

Sulfemi, Wahyu Bagja dan Hilga Minati. (2018). Meningkatkan Hasil Belajar Peserta Didik Kelas 3 SD Menggunakan Model Picture And Picture dan Media Gambar Seri. JPSD. 4 (2), 228- 242

Sulfemi, Wahyu Bagja. (2018). Pengaruh Disiplin Ibadah Sholat, Lingkungan Sekolah, dan Intelegensi Terhadap Hasil Belajar Peserta Didik Mata Pelajaran Pendidikan Agama Islam. Edukasi: Jurnal Penelitian Pendidikan Agama dan Keagamaan. 16 (2), 166-178.

Sulfemi, Wahyu Bagja., \& Yuliana, D. (2019). Penerapan Model Pembelajaran Discovery Learning Meningkatkan Motivasi Dan Hasil Belajar Pendidikan Kewarganegaraan. Jurnal Rontal Keilmuan Pancasila dan Kewarganegaraan, 5(1), 17-30.

Sulfemi, Wahyu Bagja.(2019). Bergaul Tanpa Harus Menyakiti. Bogor : Visi Nusantara Maju.

Sulfemi, Wahyu Bagja. (2019). Menanggulangi Prilaku Bullying Di Sekolah. Bogor : Visi Nusantara Maju.

Sulfemi, Wahyu Bagja dan Yuliani, Nunung. (2019). Model Pembelajaran Contextual Teaching And Learning (CTL) Berbantu Media Miniatur Lingkungan Untuk Meningkatkan Hasil Belajar IPS. Edunomic : Jurnal Ilmiah Pendidikan Ekonomi Fakultas Keguruan Dan Ilmu Pendidikan. 7 (2) . 73-84 